\title{
Needs Analysis for Informatics Engineering Students as a Basis to Develop Teaching Materials on English for Specific Purposes
}

\author{
Kadek Yogi Susana and Agus Ari Iswara
}

STMIK STIKOM Indonesia

yogi.susana@stiki-indonesia.ac.id and agus_ari_iswara@yahoo.co.id

\begin{tabular}{|l|l|}
\hline Received: $30 / 08 / 2018$ & Revised: 14/03/2019 \\
\hline How to cite (in APA style): & Published: 30/04/2019 \\
Bagiada, I, N, B. (2019). Lexicons Per-tuak-an on Mambal Village Community of Badung Bali Regency in Ecolinguistic \\
Perspective. RETORIKA: Jurnal Ilmu Bahasa, 5(1), 56-67. doi: http://dx.doi.org/10.22225/jr.5.1.967.56-67 \\
\hline
\end{tabular}

Abstract-This research aims is to find and describe students' needs for ESP and find out students' perceptions of ESP teaching that has been running. This research is a descriptive research with a qualitative approach. The subject of this research was the first semester students of Informatics Engineering of STMIK STIKOM Indonesia. The data collection was done using online questionnaire on google form application. The data obtained were then classified so that the needs of Informatics Engineering students on English learning can be identified and then be described. The results of this research can be used as a reference for subsequent research, namely syllabus planning and the development of teaching materials of ESP. Referring to students awareness of the importance of speaking skill and the also the need of having grammar lessons as basis for their practical competence, it is a task for ESP lecturer to apply teaching strategies which are interesting, motivating and engaging to cover both areas in equal portion.

Keywords: Development of teaching materials; English for Specific Purposes; needs analysis

\section{INTRODUCTION}

Language competence is one of the important provisions for students in meeting the demands of the workforce, especially for students with fields of science that are closely related to the mastery of good English such as Informatics Engineering students who deal with developments in digital technology in the disruption 4.0 era. As an international language, English has an important and strategic role in improving individual's competence both in the fields of oral and written communication. In terms of developing English language teaching at the higher education level, the English language learning model is not only done with the General English learning model but also using the English learning model specifically (English
For Specific Purposes). This learning model sould necessarily be carried out in accordance with the needs of students in their respective fields.

It is generally acknowledged that English for Specific Purposes focuses on relating the process of teaching and learning English to the learners' communicative needs. ESP teachers know what the learners need English for, the content of the language course could be tailored accordingly and the teaching process should focus on these specific needs (Hutchinson \& Waters, 1987). As a result, curriculum content and developing teaching materials must be based on needs analysis. Needs should be formulated in terms of goals and objectives which, in turn, could be considered the foundation for developing tests, materials, teaching activities and evaluation 
strategies (Brown, 1995).

Needs analysis should be an on-going process carried out during the life of each course since the learners' needs are changing too (Hutchinson \& Waters, 1987). This can help teachers take the changes into account in a way that encourages students' progress. Analysis of the target situation can tell us what students do with the chosen foreign language. Teachers also need to know how students learn to do what they do with English language. The role of needs analysis in a skills-centred approach is to provide a basis for discovering the underlying competences that enable students to perform in the target situation and to enable the course designer to discover the potential knowledge and abilities that the learners bring to the ESP class. This approach considers the learner as a user of language rather than as a learner of language.

When teaching students in technical fields, all of the above four objectives are considered. Thus, it is important for students to become proficient in all the four skills, i.e. reading, writing, listening and speaking, while it is equally important for them to be aware of the cultural aspects, i.e. become proficient in the so-called soft-skills, as well. At the same time, having positive feelings about the taught subjects and being able to transfer knowledge and skills from one subject to another are just as essential. In order to reach these objectives teachers need to know what students need in terms of knowledge and skills in the taught language, and to this end, the best option is to run a needs analysis. Obviously teachers need to be flexible and adaptable if they are interested in satisfying the students' needs with regard to the knowledge and the skills they feel are important when learning a foreign language, English in this particular case, and they also have to be willing to use the feedback they get from the students in order to improve the whole teaching-learning process.

A small scale research conducted by Ali (2015) was looking at ESP Teacher Education Model in Indonesia. He found that some factors were not sufficiently fulfilled by the teachers lead to serious issues in its pedagogical implementation (Ali, 2015). For example, the ESP teachers did not have any qualification in English teaching. Even though some of them possessed English teaching qualifications, they were mostly inexperienced and new. Consequently, they have insufficient ESP knowledge. This is of course affecting their teaching capacity. Furthermore, Paniya (2008) in her research claimed that due to the inadequacy, the ESP instruction in Indonesia has been limited to specialized lexicon and sentence structures and this ignored the learners' interest (Paniya, 2008). Yet, not many research are conducted to examine the ESP teaching at tertiary level in Indonesia. Some of them were conducted by Marwan (2009) and found that the problem lied in students "motivation and unmatched syllabus with the students' needs of English learning (Marwan, 2009). Poedjiastutie and Oliver (2017) focused on exploring students' learning needs. The findings showed students at the target university have pragmatic reasons for learning English. Those include international collaboration, better life opportunities, business establishment international employment competitive, better international test outcomes, cultural awareness, and understanding English journals and books (Poedjiastutie \& Oliver, 2017). In the same year, Poedjiastutie (2017) explored the challenges faced by English for specific purposes (ESP) program. The research emphasized that there is a need for continuous NA approaches to be undertaken so that the ever-changing gaps between what has been taught and what are the current pedagogical practices in regards to English teaching and learning can be accurately identified (Poedjiastutie, 2017).

According to the gap between the existing researches and aspect needed to be explored in ESP program, of the four types of needs this present research applied the third type, namely the subjective needs analysis, which focuses on the learners' interest, wants, reasons for attending the course, and expectations. Moreover, this research also considered that the teacher-student relationship, the classroom environment, and in that line of thought the students' perception of their teacher are all part of this type of needs analysis, i.e. the subjective one, and an integral part of a successful course. So far, English has become a compulsory subject taken by all Informatics Engineering students in the first semester to the fourth semester. In the first and second semesters, the teaching materials given is general english to introduce the basics of both active and passive English competence. Meanwhile, for the third and fourth semester, teaching material leads to a more specific material such as English for IT students. However it has different variation based on the lecturer's designs. This is because there is no standard textbooks that specifically focus on English language skills according to the major 
taken by students in each research program. To overcome this, needs analysis should be conducted as a basis to prepare ESP learning materials that can help students meet qualifications required in the workplace. Based on this situation, the main objective of this research is to analyze the need for learning English in accordance with the needs and interests of STMIK STIKOM Indonesia majoring Informatics Engineering so that the expected results of learning with specific objectives can be applied.

\section{METHODS}

This research is a descriptive research with a qualitative approach. Qualitative descriptive research is aimed at describing existing phenomena, which pays more attention on the characteristics, quality, and interrelationship between activities (Sukmadinata, 2011). In addition, descriptive research does not provide treatment, manipulation or alteration in the variables studied, but describes a real condition. The only treatment given is the research itself, which can be done through observation, interviews, or documentation. This research involved first semester students of Informatics Engineering as respondents. They were involved as sources of information related to their perceptions of ESP teaching that the basis for developing and improving the quality of ESP teaching materials can be obtained. The data collection was done through two types of questionnaire distributions, namely google form with scale and paragraph type. The subjective needs analysis in this research focused on the learners' interests, wants, reasons for attending the course, and expectations. The questionnaires were given to first semester students from four different classes. Data analysis was done in some steps including data reduction, data display, and conclusion drawing/data verification.

\section{RESULTS AND DISCUSSION}

The questionnaires were responded by 104 students from four classes. A certain level of subjectivity can be expected from the respondents due to the fact that, even though questionnaires are submitted anonymously, generally speaking, students still consider the teacher's feelings, especially since they know that they will interact with the same teacher for the following two semesters. Moreover, the type of needs analysis we decided to implement was the subjective one, as mentioned above, thus subjectivity on the part of the respondents was to be expected. Thus, on one hand, a general positive feedback can be generated by the fact that students do not want to offer negative feedback out of consideration for their teacher, and on the other hand, they may be afraid of repercussions in case they provide negative feedback. In certain instances, students may be influenced in their responses by the fact that they think this is what is expected of them, i.e. a positive answer is what the teacher expects. The following sections elaborate students' perspectives both in the types of scale and paragraph questionnaires describing students' interest, wants and expectations particularly on the learning style.

Students' interest is important in learning and interests also play a important role in developing student's thinking ability. English language is one of the main languages widely used all over the world. It is very important for teachers to be able to teach and arouse students' interest in following the lesson in the classroom. For some students, learning English as a second language is one of the most difficult subjects they have learnt. Due to the difficulties in learning, English language can make students lose their interest easily. Interest is one of the strongest motivations for learning English. The results of questionnaire as shown in Table 1 indicate that students have a good interest in learning English and have a motivation to improve themselves in the next phases of learning English.

Table 1

Indicator that students have a good interest and motivation in learning English

\begin{tabular}{lcccc}
\hline \multicolumn{1}{c}{ Questions } & \multicolumn{4}{c}{ Scales } \\
& 1 & 2 & 3 & 4 \\
& Strongly Disagree & Disagree & Agree & $\begin{array}{c}\text { Strongly } \\
\text { Agree }\end{array}$ \\
\hline $\begin{array}{l}\text { Learning English is challenging but I } \\
\text { enjoy it }\end{array}$ & 5 & 3 & 74 & 58 \\
& {$[3,6 \%]$} & {$[2,1 \%]$} & {$[52,9 \%]$} & {$[41,4 \%]$} \\
\hline \hline
\end{tabular}




\begin{tabular}{|c|c|c|c|c|}
\hline \multirow{2}{*}{$\begin{array}{l}\text { I want to learn English so that I have } \\
\text { more skills besides the knowledge that I } \\
\text { research }\end{array}$} & 6 & 1 & 49 & 84 \\
\hline & {$[4,3 \%]$} & {$[0.7 \%]$} & [35\%] & [60\%] \\
\hline \multirow{2}{*}{$\begin{array}{l}\text { I believe that learning English is im- } \\
\text { portant for getting a good job after } \\
\text { graduating from university }\end{array}$} & 5 & 2 & 47 & 86 \\
\hline & {$[3,6 \%]$} & {$[1.4 \%]$} & {$[33,6 \%]$} & {$[61,4 \%]$} \\
\hline \multirow{2}{*}{$\begin{array}{l}\text { If the ESP course is an elective course, } \\
\text { I will still choose to take this course }\end{array}$} & 0 & 10 & 87 & 43 \\
\hline & {$[0 \%]$} & {$[7,1 \%]$} & {$[62,1 \%]$} & {$[30,7 \%]$} \\
\hline \multirow{2}{*}{$\begin{array}{l}\text { In my opinion, ESP has benefits for the } \\
\text { needs of my English language learning } \\
\text { in the future }\end{array}$} & 6 & 2 & 69 & 63 \\
\hline & {$[4,3 \%]$} & {$[1,4 \%]$} & {$[49,3 \%]$} & {$[45 \%]$} \\
\hline \multirow{2}{*}{$\begin{array}{l}\text { I like reading English articles about IT } \\
\text { to sharpen my English language skills }\end{array}$} & 6 & 14 & 76 & 44 \\
\hline & {$[4,3 \%]$} & {$[10 \%]$} & {$[54,3 \%]$} & {$[31,4 \%]$} \\
\hline \multirow{2}{*}{$\begin{array}{l}\text { As a student in the IT field, I need to } \\
\text { equip myself with specific English lan- } \\
\text { guage skills in the field of technology }\end{array}$} & 5 & 3 & 61 & 71 \\
\hline & {$[3,6 \%]$} & {$[2,1 \%]$} & {$[43,6 \%]$} & {$[50,7 \%]$} \\
\hline \multirow{2}{*}{$\begin{array}{l}\text { When I have difficulty understanding } \\
\text { the meaning of IT terms in English, I } \\
\text { search for the meaning on the internet }\end{array}$} & 2 & 5 & 69 & 63 \\
\hline & {$[1,4 \%]$} & {$[3,6 \%]$} & {$[49,6 \%]$} & {$[45,3 \%]$} \\
\hline \multirow{2}{*}{$\begin{array}{l}\text { I practice English independently out- } \\
\text { side the classroom }\end{array}$} & 3 & 37 & 81 & 29 \\
\hline & {$[2,1 \%]$} & {$[19,3 \%]$} & {$[57,9 \%]$} & {$[20,7 \%]$} \\
\hline \multirow{2}{*}{$\begin{array}{l}\text { I have a self-target of increasing my } \\
\text { English language skills in next semester }\end{array}$} & 6 & 3 & 80 & 51 \\
\hline & {$[4,3 \%]$} & {$[2,1 \%]$} & {$[57,1 \%]$} & {$[36,4 \%]$} \\
\hline
\end{tabular}

The results of the questionnaire generally showed that students had high interest in learning English even though they still faced some obstacles needed to be resolved. A total of 74 students $(52.9 \%)$ stated that they enjoyed learning English even though it was considered a challenging lesson. Judging from the motivation to learn English, a total of 84 students $(60 \%)$ said they wanted to learn English in order to have supplementary skills in addition to skills in IT field and get good jobs after graduating from university $(86$ students or $61.4 \%$ ). Regarding the important role of English for Specific Purposes, the results of the questionnaire indicate that students have a good interest in ESP and will still choose to take ESP courses even if ESP is an elective course (87 students or $62.1 \%$ ). Furthermore, as many as 69 students $(49.3 \%)$ realized that ESP has benefits for the needs of learning English in the future. In terms of the students' autonomy in equipping themselves with English language skills, the questionnaire showed a percentage of positive perceptions where as many as 76 students $(54.3 \%)$ stated that they enjoyed enhancing their English language skills by reading articles about IT and 81 students (57, 9\%) stated that they practiced using English independently outside the classroom meetings. This is in line with the next statement where as many as 71 students $(50.7 \%)$ revealed that as students majoring IT, they need to equip themselves with specific English language skills in the field of technology. Judging from the ability to use technology as a way out to solve the difficulties faced when learning English, as many as 69 students $(49.6 \%)$ tried to find the meaning of the term IT that was not understood on the internet. A large number of students, 80 students $(57.1 \%)$ stated that they had a target of increasing English language skills in each semester.

The results of the google form questionnaire with paragraph types revealed more details about students' interest in learning English. According to the question whether English is important to be mastered by IT students, the responses can be classified into two main reasons including the fact that IT is closely related to English and English helps IT students to get job easier. Students' responses can be seen in the following data:

1. Because students majoring IT depend on computers. Computers mainly use English and many application use English so we have to learn English

2. Because there are many English terms in IT, IT also continues to grow if you can master IT and English at the same time, making it easy to find good jobs later

3. Because coding is mostly in English

4. Because all programs and applications on the computer are almost all in English and because English can provide more value 
when competing to find job later.

Students' responses on the importance of English are in line with the finding in a research conducted by Poedjiastutie and Oliver (2017) stating that a number of other students also expressed a belief that by being able to communicate in English fluently, other people will attribute positive characteristics to them. In this way it is a skill that will advantage them in their career. In the questions related to students' independent efforts to improve their English proficiency, most students stated that they practiced speaking skills and tried to increase their vocabulary as shown in the following excerpts:

1. Practice talking and learning to master English vocabulary.

2. Learn English vocabulary related to IT.

3. Continue to practice speaking, listening or conversation with friends and lecturers.

Students' awareness of the important role of English in improving their portfolios when competing for jobs were expressed in responses below:

1. Because if we can speak English, the company does not hesitate to accept us in the company. Because whatever conditions we have, at least we can speak nglish in general.

2. With the English language proficiency, the job applicant will have a plus point.

3. With mastering English, the opportunity to be accepted while applying a job will be wider, because I am an IT student who has good and correct English skills.

4. The fluency in English will be seen by the company when conducting interviews, whether the person is ready to work or not, and that will get more opportunities to pass in the interview.

5. Very influential because in applying for work there must always be a condition when we must be able to understand English, especially in speaking.

The above data emphasized that students majoring IT were aware that English play an important role when they have to face the competition required by the industry. In other words, most of the students understood the importance of English as a means of communication with which they can adapt themselves to new improvements in technology and other sciences. This awareness led students to express responses that they did independent learning and motivated themselves to get better grade in next semester. Learning makes students gain new knowledge and skills and motivation pushes us or encourage us to go through the learning process (Wimolmas, 2013). Ellis (1997) stated that as teachers, we need to explore more fully the factors that are involved in motivating students to perform tasks well because this is something that teachers have some control over (Ellis, 1997). Therefore, it is important to find out the underlying possible factors in which affect students' motivation and interest in learning English (Wimolmas, 2013). Based on the responses, ESP teachers should make sure that students get sufficient exposure to English being used in the field of IT as it is the main factor that motivate them to learning English.

The next part of questionnaire referred to the aspects and activities the students appreciated or enjoyed in particular and wanted to get in the ESP class. Most aspects referred exclusively to the course, ranging from the most wanted skill to learn and how the lectures should be delivered.

Table 2

The students' responses based on the scale type of google form questionnaire

\begin{tabular}{|c|c|c|c|c|}
\hline \multirow[b]{2}{*}{ Questions } & \multicolumn{4}{|c|}{ Scales } \\
\hline & $\begin{array}{c}1 \\
\text { Strongly Disagree }\end{array}$ & $\begin{array}{c}2 \\
\text { Disagree }\end{array}$ & $\begin{array}{c}3 \\
\text { Agree }\end{array}$ & $\begin{array}{c}4 \\
\text { Strongly } \\
\text { Disagree }\end{array}$ \\
\hline $\begin{array}{l}\text { In ESP class, I need speaking skill } \\
\text { the most }\end{array}$ & $\begin{array}{c}5 \\
{[3,6 \%]}\end{array}$ & $\begin{array}{c}3 \\
{[2,1 \%]}\end{array}$ & $\begin{array}{c}70 \\
{[50 \%]}\end{array}$ & $\begin{array}{c}62 \\
{[44,3 \%]}\end{array}$ \\
\hline $\begin{array}{l}\text { In ESP class, I need writing skill the } \\
\text { most }\end{array}$ & $\begin{array}{c}3 \\
{[2,1 \%]}\end{array}$ & $\begin{array}{c}9 \\
{[6,4 \%]}\end{array}$ & $\begin{array}{c}74 \\
{[52,9 \%]}\end{array}$ & $\begin{array}{c}54 \\
{[38,6 \%]}\end{array}$ \\
\hline $\begin{array}{l}\text { In ESP classes, I need grammar skill } \\
\text { the most }\end{array}$ & $\begin{array}{c}4 \\
{[2,9 \%]}\end{array}$ & $\begin{array}{c}2 \\
{[1.4 \%]}\end{array}$ & $\begin{array}{c}73 \\
{[52,1 \%]}\end{array}$ & $\begin{array}{c}61 \\
{[43,6 \%]}\end{array}$ \\
\hline $\begin{array}{l}\text { In ESP classes, I need reading skill } \\
\text { the most }\end{array}$ & $\begin{array}{c}4 \\
{[2,9 \%]}\end{array}$ & $\begin{array}{c}1 \\
{[0,7 \%]}\end{array}$ & $\begin{array}{c}79 \\
{[56,4 \%]}\end{array}$ & $\begin{array}{c}56 \\
{[40 \%]}\end{array}$ \\
\hline
\end{tabular}




\begin{tabular}{lcccc}
\hline \hline In ESP class, I need listening skill the & 4 & 6 & 69 & 61 \\
most & {$[2,9 \%]$} & {$[4,3 \%]$} & {$[49,3 \%]$} & {$[43,6 \%]$} \\
In the ESP class, I need vocabulary & 4 & 4 & 68 & 64 \\
skill the most & {$[2,9 \%]$} & {$[2,9 \%]$} & {$[48,6 \%]$} & {$[45,7 \%]$} \\
I want to increase the knowledge of & 5 & 1 & 62 & 72 \\
grammar especially those commonly & {$[3,6 \%]$} & {$[0,7 \%]$} & {$[44,3 \%]$} & {$[51,4 \%]$} \\
used in IT texts & 4 & 2 & 61 & 72 \\
I want to improve my vocabulary & {$[2,9 \%]$} & {$[1,4 \%]$} & {$[43,9 \%]$} & {$[51,8 \%]$} \\
knowledge to understand IT texts & 2 & 7 & 92 & 39 \\
$\begin{array}{l}\text { I can understand the lecturers' expla- } \\
\text { nations using English and Indonesian }\end{array}$ & {$[1,4 \%]$} & {$[5 \%]$} & {$[65,7 \%]$} & {$[27,9 \%]$} \\
I can understand the lecturers' expla- & 5 & 38 & 76 & 21 \\
nation using English & {$[3,6 \%]$} & {$[27,1 \%]$} & {$[54,3 \%]$} & {$[15 \%]$} \\
$\begin{array}{l}\text { By researching ESP, I want to im- } \\
\text { prove my ability to understand IT }\end{array}$ & 5 & 1 & 66 & 67 \\
textbooks in English & {$[3,6 \%]$} & {$[0,7 \%]$} & {$[47,5 \%]$} & {$[48,2 \%]$} \\
\hline
\end{tabular}

The data in the questionnaire emphasize the aspects of what students want to get in the ESP class so that they can be used as a basis for developing teaching materials. Regarding the statement of competency that wants to be studied, students provided fairly similar answers because most students chose the scale 'strongly agree' on the wish to learn speaking skill (70 students or 50\%), writing skill (74 students or $52.9 \%$ ), grammar skill (73 student or $52.1 \%$ ), reading skill (79 students or $56.4 \%$ ), listening skill (69 students or $49.3 \%)$, and vocabulary skill (68 students or $48.6 \%$ ).

As one can notice in Table 2, students have expressed their appreciation of certain types of activities and at the same time a certain level of dislike for others. More specifically, a number of 72 students $(51.4 \%)$ expressed a desire to increase knowledge of grammar especially those commonly used in IT texts and students stongly agreed on the statement mentioning the desire to improve their ability to understand IT textbooks in English by researching vocabulary (72 students or $51.8 \%$ ). For some reason, grammar and vocabulary tends to be amongst the most favoured types of activities, probably because it is more rigid in that it basically requires students to learn and observe rules. Thus, students do not have to be put in the situation where they have to actively express their ideas through speaking or writing activites.

When dealing with vocabulary related activities, students expressed their preference for these because all vocabulary issues were related to their domain of interest, and they were all aware of the importance of researching field-related vocabulary, relevant in their field of research and possibly in their future jobs.
The statement on the method of delivering lecture material with a mix of English and Indonesian compared to the delivery of only using English shows that students (92 respondents or 65.7\%) agreed more if lecturers use both languages in delivering material. Further elaboration on what the students want from English class is shown by the data of paragraph type questionnaire. Students gave reasons regarding their wish in researching speaking skill rather that writing skill as seen in the following data:

1. Speaking, because it really helps me in my work and in courses too

2. I want to learn both, but I want to improve in speaking

3. Speaking, because the more you can speak English, it will be easier for other skills

For questions on what kind of English skills are needed by IT students, most of the respondents gave the following answers:

1. In my opinion the ability that must be possessed by IT students is to master vocabulary and ability in writing

2. In speaking because it is very useful in presentations

3. English language skills that are often used in the IT field and in the world of work

4. What is needed is speaking and writing.

The students responses underlined the importance of mastering practical skills both in speaking and writing especially related with IT and language used in the workplace. Regarding the type of material that makes students enthusiastic about learning, students mostly gave answers on the material focusing on practical skills as seen by the following data: 
1. Speaking by playing game

2. Presentation, because it fosters my lack of confidence

3. Lectures that include more practice, because with practice being able to get used to working directly

4. Courses that are in accordance with our daily habits, for example soft skills

Students mentioned different practical skills including exposures on speaking, presentation and soft skills used in daily basis at work. In other words, students got enthusiastic in learning English when they were given chance to focus on practical skills especially speaking related to daily activities and workplace. In their responses, students also approved that grammar increased their selfconfidence in speaking as seen in the following data:

1. Yes, because then I can improve the quality of my English language

2. Of course, by learning grammar and mastering it I will be confident in speaking with native speakers

3. With us mastering grammar, we no longer need to fear speaking

4. Yes. Because of that we can arrange good procedures using English

5. I think YES. Because, when I know / understand about grammar in speaking, I will be more confident to speak to others in English.

6. Yeah, because if the grammar is lacking then we won't have the confidence to speak in English

Despite the fact of students' high preference in having speaking activities meant to foster their ability to communicate orally, students were aware of the situation in which grammar was the main obstacle in their practice. Thus, they needed to have exposure on how to use correct grammar in order to prevent making mistakes. Todea and Demarcsek (2017) highlighted that there is another psychological mechanism which functions in adult learners: the fear of being judged by their peers. In other words, students are aware that they make mistakes when they speak, and choose not to share their ideas and opinion for fear of producing ungrammatical utterances and being judged by other students.

However, despite the awareness of the role of grammar in enhancing confidence, students gave different views when responding to statements whether the time to research grammar would be given a larger portion than learning speaking and writing skills. Most of the students stated that they were more likely to choose to prioritize the portion of time to learn practical skills including speaking and writing rather than grammar as seen in the following data excerpt:

1. No, I prefer speaking

2. Of course because it will help in speaking

3. Not. Because even if we master grammar, if it's not balanced with speaking and writing skills it won't work

4. I want to learn speaking or writing. In order to more quickly master the vocabulary and vocals in English

5. No because I prefer speaking or writing

However, a small number of students answered that they wanted to learn more about grammar as a basis for developing speaking and writing skills as seen in the following responses:

1. Yes because grammar is the basic for learning English

2. Yes, because in my opinion grammar is my basis so I can understand speaking and writing

Besides that, there are also some students who answer that they want to have equal division of the time between the three competencies. This part of questionnaire gave highlight on students' favor in having grammar exercises eventhough they were fully aware that productive skills are important to support their future career. Findings in this part of questionnaire are also found in a research by Poedjiastutie and Oliver (2017) in which other students also described how they would like teachers to make it a priority to equip them with the necessary oral communication skills, instead of simply teaching grammar (Poedjiastutie \& Oliver, 2017). The reasons they provided for this included their belief that language is learnt for the purpose of communication and that it is not learnt by heart. In a similar vein, another participant described how people express ideas through speaking not through grammar. Yet another participant described her belief that just learning English through the teaching of grammar presented obstacles when trying to speak.

Referring to the position of grammar in ESP class, grammar can basically play two parts in ESP learning: one is to enhance 
comprehensible input and the other is to monitor effective output. To enhance comprehensible input means that learners use grammar knowledge they have learnt to solve some puzzles in their ESP reading comprehension (Chen, 2016). When learners cannot understand the meaning of a complicated sentence, they need to analyze the sentence structure, the functions and interrelation of sentence components in order to comprehend the sentence. To monitor effective output means monitoring the oral or written expressions.

Many learners have learnt ESP for several years, but they would make some mistakes in the oral or written expressions. It shows that they have not made the best of their mastered grammar knowledge to monitor and adjust the ESP learning output. Therefore, by means of grammar learning, ESP learners' grammar competence is cultivated through learning procedural knowledge and declarative knowledge. To sum up, in learning ESP, grammar can not only help ESP learners construct more accurate sentences but also help learners use various structures to express thoughts in ESP communication occasions. Therefore, grammar enables students to control the way they shape words into sentences and paragraphs. The teachers should keep a balance between grammar and communication, as there is no communication without correct grammar.

Chen (2016) also stated that fluency and accuracy are allies not enemies, and grammar and communication are complimentary since they shape and influence each other, and internalized grammatical knowledge will enable effective communication and interaction to take place (Chen, 2016). Hence, communicative approach can be used to teach English grammar; teachers help ESP learners to notice and structure by focusing on specific forms and meanings, and guide ESP learners' own attention to grammar and design grammar learning tasks that help to teach them skills of ESP, such as reading, speaking, listening or writing, in order for them to utilize grammar for their own communication.

ESP courses are meant to prepare specialists who are able to use the English language as the main professional means of communication in their future jobs and in reallife situations (Syvak, 2018). Thus, it is essential to elaborate students' expectations in ESP class in order to assist them experience the quality learning process. The final question was actually the most important because it openly asked for suggestions from the students regarding activities that they considered useful to be approached in order to better meet their needs. The statements in this section were in correlation with the previous section with a more detailed elaboration on students' expectation on how they can experience better learning process. Students responses can be observed in the following table.

Table 3

Students' responses

\begin{tabular}{|c|c|c|c|c|}
\hline \multirow[b]{2}{*}{ Questions } & \multicolumn{4}{|c|}{ Scales } \\
\hline & $\begin{array}{c}1 \\
\text { Strongly Disagree }\end{array}$ & $\begin{array}{c}2 \\
\text { Disagree }\end{array}$ & $\begin{array}{c}3 \\
\text { Agree }\end{array}$ & $\begin{array}{c}4 \\
\text { Strongly } \\
\text { Agree }\end{array}$ \\
\hline $\begin{array}{l}\text { Guest lectures from companies or } \\
\text { agencies should be invited to ESP } \\
\text { class }\end{array}$ & $\begin{array}{l}4 \\
{[2,9 \%}\end{array}$ & $\begin{array}{c}18 \\
{[12,9 \%]}\end{array}$ & $\begin{array}{c}85 \\
{[60,7 \%]}\end{array}$ & $\begin{array}{c}33 \\
{[23,6 \%]}\end{array}$ \\
\hline $\begin{array}{l}\text { Teaching ESP should be done with } \\
\text { independent project assignments } \\
\text { I want to produce one final project in }\end{array}$ & $\begin{array}{c}6 \\
{[4,3 \%]}\end{array}$ & $\begin{array}{c}36 \\
{[25,9 \%]}\end{array}$ & $\begin{array}{c}71 \\
{[51,1 \%]}\end{array}$ & $\begin{array}{c}26 \\
{[18,7 \%]}\end{array}$ \\
\hline $\begin{array}{l}\text { English class as an output for one } \\
\text { semester (example: tutorial videos in } \\
\text { IT, essays about IT) }\end{array}$ & $\begin{array}{c}6 \\
{[4,3 \%}\end{array}$ & $\begin{array}{c}15 \\
{[10,7 \%]}\end{array}$ & $\begin{array}{c}75 \\
{[53,6 \%]}\end{array}$ & $\begin{array}{c}44 \\
{[31,4 \%]}\end{array}$ \\
\hline $\begin{array}{l}\text { Teaching ESP should use role plays } \\
\text { to practice speaking English at work- } \\
\text { place }\end{array}$ & {$[0,7 \%]$} & $\begin{array}{c}17 \\
{[12,1 \%]}\end{array}$ & $\begin{array}{c}96 \\
{[68,6 \%]}\end{array}$ & $\begin{array}{c}26 \\
{[18,6 \%]}\end{array}$ \\
\hline $\begin{array}{l}\text { ESP includes the introduction of } \\
\text { application of English in the work- } \\
\text { place }\end{array}$ & {$[0,7 \%]$} & $\begin{array}{c}9 \\
{[6,5 \%]}\end{array}$ & $\begin{array}{c}95 \\
{[68,3 \%]}\end{array}$ & $\begin{array}{c}34 \\
{[24,5 \%]}\end{array}$ \\
\hline $\begin{array}{l}\text { Class activities in ESP should be } \\
\text { done in pair work }\end{array}$ & $\begin{array}{c}5 \\
{[3,6 \%]}\end{array}$ & $\begin{array}{c}15 \\
{[10,8 \%]}\end{array}$ & $\begin{array}{c}83 \\
{[59,7 \%]}\end{array}$ & $\begin{array}{c}36 \\
{[25,9 \%]}\end{array}$ \\
\hline $\begin{array}{l}\text { Class activities in ESP should be } \\
\text { done in group work }\end{array}$ & $\begin{array}{c}1 \\
{[0,7 \%}\end{array}$ & $\begin{array}{c}6 \\
{[4,3 \%]}\end{array}$ & $\begin{array}{c}80 \\
{[57,1 \%]}\end{array}$ & $\begin{array}{c}53 \\
{[37,9 \%]}\end{array}$ \\
\hline
\end{tabular}




\begin{tabular}{lcccc}
\hline ESP class activities should be done & 8 & 44 & 66 & 22 \\
individually & {$[5,7 \%]$} & {$[31,4 \%]$} & {$[47,1 \%]$} & {$[15,7 \%]$} \\
$\begin{array}{l}\text { I hope that ESP lecturers can provide } \\
\text { interactive material and put emphasis }\end{array}$ & 5 & 6 & 85 & 44 \\
on practical skills & {$[3,6 \%]$} & {$[4,3 \%]$} & {$[60,7 \%]$} & {$[31,4 \%]$} \\
\hline
\end{tabular}

In this part of the questionnaire, questions are given to explore the learning process needed by students in ESP subject both in the form of teaching methods and the materials. The results of the questionnaire revealed that a total of 85 students or $60.7 \%$ stated that ESP teaching should bring Englishspeaking guest lectures from companies or agencies.

Poedjiastutie and Oliver (2017) put emphasis on this need by stating that where English is a foreign language, such as in Indonesia, it can be very difficult for language learners to find opportunities to use it for communicative purposes because the society does not use it for daily interactions (Poedjiastutie \& Oliver, 2017). Yet wider exposure to English would give students greater opportunities for using and, therefore eventually learning the target language. For example, this can be done by teachers inviting native speakers or expatriates who are living locally to come to their classes.

In the next statement, as many as 71 students $(51.1 \%)$ stated that ESP teaching should be carried out by giving independent project assignments. Regarding the final project in the ESP class, students expressed agreement that a total of 75 students $(53.6 \%)$ chose to agree and 44 people (31.4\%) stated strongly agree on the wish to produce one final project as an learning output in the form of tutorial videos in IT, essays about IT and others. In this context, the term project refers to various tasks that students had to perform either on their own or in a group, and which usually generated a product-like outcome (presentation, essay, report, video etc.). For example, several students in technical fields had to work in groups in order to prepare a presentation of a science-fiction device, which included the actual design (created by them), the technical details, a description of how it functioned and what it was used for. Some even used short videos in order to illustrate all these aspects. Yet despite the fact that at the moment this type of project-based activity seemed successful from the lecturer's perspective, in reality it was appreciated only by few students because these activities are time-consuming, require vision and imagination, and most students were not very willing to invest much of their time in these.
Nevertheless, when requested to suggest activities which would improve their knowledge and skills in English, the number of respondents recommending projects covered more than half of total respondents (75 students or $53.6 \%$ agreed and 44 students or $31.4 \%$ strongly agreed).

Regarding the teaching method, as many as 95 students or $68.6 \%$ of total respondents approved that ESP teaching should use more role play to improve speaking skills used at work. Even though speaking is in fact one of major challenged that students faced in daily classroom meetings and despite the fact that most students did not enjoy a high level of appreciation, as one can see from the responses provided for the statement, role play was requested by more than half of the total respondents, proving that students are aware of the need to exercise their speaking skills in general, as well as their public speaking skills. However, although the students indicated that they want more opportunities to develop their oral communication skills, the way the current ESP pedagogy is organised means it is difficult for this need to be met. Currently many of ESP classes at the target university and, in fact, throughout Indonesia provide only a minimum amount of spoken English exposure (Wati, 2011)

In a more general statement, 95 students or $68.3 \%$ stated that ESP teaching is expected to include the introduction of English application in the workplace. The questionnaire statement regarding the pattern of activities in the ESP class shows that students tended to choose to do it in pair work (as many as 83) $(59.7 \%)$ and in group work (in groups) as many as 80 students $(57.1 \%)$ when compared to the individual project. Most students (85 respondents or $60.7 \%$ ) also expected that the material delivered can be interactive and emphasize practical skills. Students' perceptions of learning needs were also obtained through paragraph type questionnaires which included five statements about motivation, classroom's situation, teaching media and teaching approaches used by lecturers in classroom.

In general, students stated that they will be motivated to actively involved in speaking activities because of the awareness that English 
plays an important role in adding value to their portfolio as future programmers. Students' answers can be seen as follows:

1. The number of job needs that require English skills so that of course we have to get used to it

2. Because in the world of technology today communication with English is necessary and moreover English is an international language

3. To be able to become a programmer and find out all the application applications in question. Because all of them use English

4. Because English is an international language and is also very much needed when we are doing programming because there are many who use English

5. What motivates me is that having good English skills and IT skills will make me easier to get a good job

In relation to the classroom's atmosphere that students wanted to experience in ESP class, majority of students mentioned that they needed comfortable and interactive situation, some mentioned about the need to be given challenging practices:

1. Interacting among students, also between lecturers in English, and active in English

2. Lecture atmosphere that is diligent in communicating with English

3. Comfortable and interactive

4. The atmosphere can arouse all students, such as giving challenges to question and answer sessions

5. Both individuals and groups

6. Practice speaking English and more sample questions

In the next question, students acknowledged that they needed to have final project at the end of the ESP class with reasons stated below:

1. Yes, with the final project I was able to develop the abilities that I have

2. Yes. Because with the final projetc we are required to do it to the fullest

3. Make something like a video tutorial on how to learn English for the IT field

4. Yes. Because, effective projects are very helpful in improving the ability to speak English.

5. Yes. Because in making a project it must be able to speak English
The project work without doubt trains learners to develop their communication skill but it apparently also contributes to the training of the 'whole person'. The research by Raof and Yusof (2006) on the role of project in ESP class for students of Civil Engineering revealed that learners expressed satisfaction towards the learner-centred, real play project work carried out (Raof \& Yusof, 2006). Learners felt that the activity, through interaction with practitioners in the workplace, had increased their knowledge in Civil Engineering as well as developed certain soft skills. It had also helped them become better learners of the English language and had enhanced their confidence in using the language. Furthermore, most of the students mentioned that they needed exposures on materials with interactive media (video, games, role play, etc) to help improve their ability in ESP class as seen in the following data:

1. Maybe the games because I catch more quickly about the game

2. Because games make my thinking ability and memory more accurate

3. Video. Because you can see a good way of speaking.

4. Like English videos, whether learning, film, or music, and doing a few games so as not to get bored

5. Video. Because images on videos help us interpret a text

Only few number of students answered about role play but they did not mention any specific reasons. Regarding the approach used by lecturers to teach in ESP class, students mentioned that they needed to experience teaching approach where lecturers are friendly, attentive and can understand the students limitations.

1. I want a lecturer who is more attentive and familiar with his students

2. Understand the abilities and limitations of students

3. Understand the practice, and use games to encourage students to learn more

4. Speaking in English and giving a clear explanation of all learning material so that it is easy to understand

5. Communicate with students so that there is a reciprocal relationship between students and lecturers

In other words, students needed lecturers to use personal approach in teaching. Some 
students shifted slightly and included some reference to the teacher's personality in their responses, mentioning the aspects from the teacher's behaviour or attitude that made them enjoy the course including the use of humour, for instance). Todea and Demarcsek (2017) reported that while changing one's behaviour or attitude may be improved to some extent, possessing a sense of humour is an aspect that cannot be controlled by the teacher, unfortunately; nevertheless, it has been proven that humour has always helped in achieving a positive atmosphere in the classroom, so one should strive to include it amongst his/her teaching arsenal (Todea \& Demarcsek, 2017).

Furthermore, as stated by Narjes and Sabet (2014) many ESP teachers should follow an adulthood-oriented approach and act as simultaneous teachers and counselors dealing with both linguistic and psychological needs of learners in a parallel way (Narjes \& Sabet, 2014). Therefore, in such a balanced approach, learners are more motivated and involved in self-directed learning, which is the most fundamental purpose of ESP programs. Finally, as ESP programs are essentially learnercentered, the learning needs of learners are of priority. Because these needs are variable, following a pre-determined syllabus and methodology is unreasonable. In fact, an effective ESP teacher should be continually involved in action-based theorizing about all the relevant aspects and act as an active practitioner.

ESP teachers have to take multidimensional and unpredicted responsibilities because of the on-going changing patterns of learners' needs. They should formulate certain goals and objectives, select and develop effective materials, plan appropriate courses, and evaluate the learners' patterns of development. This means that an ESP teacher cannot follow any dictated predetermined methodology as well as any priori syllabuses. Therefore, in such a complex setting, ESP teachers cannot take on traditional language delivering roles. Instead, they have to act as teachers, course designers, collaborators, researchers, and evaluators simultaneously. Moreover, ESP teachers have the most essential role to enhance the learners' instrumental and integrated motivation.

\section{CONCLUSION}

The questionnaire was both a feedback questionnaire and a needs analysis. Its purpose was to identify the types of activities that students enjoy and consequently use them more frequently during the English course. It was also meant to find out what activities students consider worth including in the English course from the perspective of their own needs as they perceive them, the major goal being to redesign the course in such a way that it best fit the students' needs. Thus, this analysis should result in a change of the design of the English course, and in order to measure its success, another questionnaire needs to be applied at the end of the second academic year to see whether the change was successful.

Thus this endeavour will not remain unechoed, some follow-up actions being planned. Needs analysis should be seen as an indispensable aspect of ESP syllabus design not only in order to improve the students' experience during the English course, but rather in order to link the present students' academic needs with their needs in their prospective employment.

After applying the questionnaire we have discovered which activities are more successful and which should be included more often in the English course from the students' viewpoint. The questionnaire has proven to be a useful instrument for the improvement of the teaching -learning process during the English course and will generate change. Yet what we consider probably the most surprising outcome of the questionnaire is not the type of activities the students favour, nor is it the type of activities they would like to focus on more during the English course. The truly surprising aspect, despite the fact that the type of questionnaire used was the so-called subjective one, is that students seem to be quite aware of their needs in terms of English knowledge and skills, i.e. they seem to have quite an objective viewpoint on what activities are useful and generate improvement of their skills and knowledge. Thus we appreciate that such needs analysis should be carried out as frequently as possible and responses should be taken into account when designing ESP courses, since the target group seems to be objectively aware of its needs.

Referring to students awareness to the importance of speaking skill and the also the need of having grammar lessons as basis for their practical competence, it is a task for ESP lecturer to apply teaching strategies which are interesting, motivating and engaging to cover both areas in equal portion. Teachers guide ESP learners to have proper and positive attitudes towards learning grammar, and 
instruct them to learn ESP grammar not only autonomously, but also cooperatively with the aim that learning grammar is better to facilitate their skills of listening, speaking, reading and writing, and accordingly, helps to improve ESP proficiency on the whole. All things considered, ESP grammar learning strategy training can not only be beneficial to reaching the final goal of grammar learning, but also to develop ESP learners' learning ability that is vital for ESP learners' learning at the university as well as even lifelong learning. In general, in order to have influential ESP courses, ESP teachers should conduct extensive studies to explore short-term and long-term needs of the participants. In fact, ESP teachers should act as action-based researchers and theoreticians, who reach more innovative findings and approaches based on specific demands of ESP settings. Therefore, the next or perhaps the most important role of an ESP teacher is acting as an active practitioner and action-based researcher.

\section{REFERENCES}

Ali, S. U. (2015). Esp Teacher Education Model in Indonesian Context. EDUKASI - Jurnal Pendidikan, 13(2), 344-354.

Brown, J. (1995). The Elements of Language Curriculum: A Systematic Approach to Program Development. New York: Heinle and Heinle.

Chen, Z. (2016). Grammar Learning Strategies Applied to ESP Teaching Theory and Practice. Language Studies, 6(3), 617-621.

Ellis, R. (1997). Second Language Acquisition. Oxford: Oxford University Press.

Hutchinson, T., \& Waters, A. (1987). English for Specific Purposes: A Learner-Centred Approach. United Kingdom: Cambridge University Press.

Marwan, A. (2009). ESP teaching challenges in an Indonesian vocational higher institution. The English Teacher, 38, 1-12.

Narjes, G., \& Sabet, S. (2014). The Most Prominent
Roles of an ESP Teacher. International Education Studies, 7(11).

Paniya. (2008). Designing ESP course for Indonesian Vocational College Students. Jurnal Pengembangan Humaniora, 8(1).

Poedjiastutie, D. (2017). The pedagogical challenges of English for specific purposes (ESP) teaching at the University of Muhammadiyah Malang, Indonesia. Educational Research and Reviews, 12(6), 338-349. https://doi.org/10.5897/ ERR2016.3125

Poedjiastutie, D., \& Oliver, R. (2017). Exploring Students' Learning Needs: Expectation and Challenges. English Language Teaching, 10 (10), 124. https://doi.org/10.5539/ elt.v10n10p124

Raof, A. H. A., \& Yusof, M. A. (2006). ESP Project Work: Preparing Learners for the Workplace. The Asian EFL Journal Quarterly, 8(1).

Sukmadinata, N. S. (2011). Metode Penelitian Pendidikan. Bandung: PT Remaja Rosdakarya.

Syvak, O. (2018). Importance of Grammar in ESP. Science and Education a New Dimension. Philology, 6(183).

Todea, L., \& Demarcsek, R. (2017). Needs Analysis for Language Course Design. A Case Research for Engineering and Business Students. (IOP Conference Series: Materials Science and Engineering).

Wati, H. (2011). The Effectiveness of Indonesian English Teachers Training Program in Improving Confidence and Motivation. International Journal of Instruction, 4(1), 79 -104 .

Wimolmas, R. (2013). A survey study of motivation in English language learning of first year undergraduate students at Sirindhorn International Institute of Technology (SIIT). In Proceedings of the 3rd International Conference on Foreign Language Learning. Bangkok: Thammasat University. 